See discussions, stats, and author profiles for this publication at: https://www.researchgate.net/publication/317005600

\title{
Examining the Role of Transmission of Chelonid Alphaherpesvirus 5
}

Article in EcoHealth · May 2017

DOI: 10.1007/s10393-017-1248-7

CITATIONS

13 authors, including:

Andrea Chaves

University of California, Davis

32 PUBLICATIONS 68 CITATIONS

SEE PROFILE

Kinndle Blanco-Peña

National University of Costa Rica

35 PUBLICATIONS 102 CITATIONS

SEE PROFILE
A. Alonso Aguirre

George Mason University

226 PUBlications 4,001 CITATIONS

SEE PROFILE

8. Andres Moreira-Soto

Charité Universitätsmedizin Berlin

50 PUBLICATIONS 340 CITATIONS

SEE PROFILE

Some of the authors of this publication are also working on these related projects:

Genetic variation of desert bighorn sheep View project

Effects of the Illegal Consumption of Sea Turtles on Environmental Security and Human Health in Northwestern Mexico View project 


\title{
Original Contribution
}

\section{Examining the Role of Transmission of Chelonid Alphaherpesvirus 5}

Andrea Chaves, ${ }^{1,2}$ A. Alonso Aguirre, ${ }^{3}$ Kinndle Blanco-Peña, ${ }^{4}$ Andrés Moreira-Soto, ${ }^{5}$ Otto Monge, ${ }^{2}$ Ana M. Torres, ${ }^{6}$ José L. Soto-Rivas, ${ }^{7}$ Yuanan Lu, ${ }^{8}$ Didiher Chacón, ${ }^{9}$ Luis Fonseca, ${ }^{9}$ Mauricio Jiménez, ${ }^{5}$ Gustavo Gutiérrez-Espeleta, ${ }^{2}$ and Michael Lierz ${ }^{1}$

\footnotetext{
${ }^{1}$ Clinic for Birds, Reptiles, Amphibians and Fish, Justus-Liebig-University Giessen, Frankfurte Str. 91-93, 35392 Giessen, Germany

${ }^{2}$ Escuela de Biología, Universidad de Costa Rica, San Jose 11501-2060, Costa Rica

${ }^{3}$ Department of Environmental Science and Policy, George Mason University, 4400 University Dr, Fairfax, VA

${ }^{4}$ Escuela de Ciencias Biológicas, Universidad Nacional, Heredia 86-3000, Costa Rica

${ }^{5}$ Centro de Investigación en Enfermedades Tropicales, Facultad de Microbiología, Universidad de Costa Rica, San Jose 2060-1000, Costa Rica

${ }^{6}$ Escuela de Medicina Veterinaria, Universidad Nacional, Heredia 86-3000, Costa Rica

${ }^{7}$ Facultad de Ciencias Agrarias, Universidad de Ciencias Comerciales, P-84, Managua, Nicaragua

${ }^{8}$ Environmental Health, Department of Public Health Sciences, University of Hawaii at Mānoa, 1960 East-West Road, Biomed D105, Honolulu, HI

${ }^{9}$ WIDECAST Costa Rica, San Jose 496-1100, Costa Rica
}

\begin{abstract}
Marine turtle fibropapillomatosis (FP) is a devastating neoplastic disease characterized by single or multiple cutaneous and visceral fibrovascular tumors. Chelonid alphaherpesvirus 5 (ChHV5) has been identified as the most likely etiologic agent. From 2010 to 2013, the presence of ChHV5 DNA was determined in apparently normal skin, tumors and swab samples (ocular, nasal and cloacal) collected from 114 olive ridley (Lepidochelys olivacea) and 101 green (Chelonia mydas) turtles, with and without FP tumors, on the Pacific coasts of Costa Rica and Nicaragua. For nesting olive ridley turtles from Costa Rica without FP, 13.5\% were found to be positive for ChHV5 DNA in at least one sample, while in Nicaragua, all olive ridley turtles had FP tumors, and 77.5\% tested positive for ChHV5 DNA. For green turtles without FP, 19.8\% were found to be positive for ChHV5 DNA in at least one of the samples. In turtles without FP tumors, ChHV5 DNA was detected more readily in skin biopsies than swabs. Juvenile green turtles caught at the foraging site had a higher prevalence of ChHV5 DNA than adults. The presence of ChHV5 DNA in swabs suggests a possible route of viral transmission through viral secretion and excretion via corporal fluids.
\end{abstract}

Keywords: chelonid alphaherpesvirus 5, Costa Rica, green turtle, fibropapillomatosis, Nicaragua, olive ridley turtle

\section{INTRODUCTION}

Electronic supplementary material: The online version of this article (doi:10.1007/ s10393-017-1248-7) contains supplementary material, which is available to authorized users.

Correspondence to: Andrea Chaves, e-mail: andreachaves.biol@gmail.com
Marine turtle fibropapillomatosis (FP) is a global neoplastic disease first observed over 75 years ago in green turtles (Chelonia mydas) in Florida (Lucke 1938; Smith and Coates 
1938) and has since been documented in all hard-shelled sea turtles species (Harshbarger 1991; Herbst 1994; Quackenbush et al. 1998; Aguirre et al. 1999). The chelonid alphaherpesvirus 5 (ChHV5) has been suggested as the etiological agent of FP (Quackenbush et al. 1998; Greenblatt et al. 2005; Alfaro-Nunez et al. 2014). Even though investigators have been able to characterize the virus (Herbst and Klein 1995; Herbst et al. 1999), all attempts at isolation have been unsuccessful (Alfaro-Nunez et al. 2016). Although FP has reached epizootic proportions in some geographic areas, and the advances achieved on the epidemiology of the disease in wild turtles (Herbst et al. 2008; Coberley et al. 2001; Coberley et al. 2001b), the relationship between exposure to ChHV5 and the proliferation of FP in wild populations still has not been determined (Coberley et al. 2001b). In addition, the association between high prevalence of FP with degradation of marine environments due to anthropogenic activities and coastal marine pollution is poorly understood (Aguirre and Lutz 2004). Elucidating these relationships is challenging, given the complex life cycle and migratory patterns of sea turtles, and the limited accessibility to their pelagic habitats.

Over the past three decades, the prevalence of FP has apparently been stable or increased in the green turtle populations of Australia, Indonesia, Brazil, and USA (Florida) (Limpus et al. 2016; Baptistotte 2016; Ehrhart et al. 2016). Recent studies demonstrate that the prevalence of FP is declining in Hawaii and Puerto Rico (Murakawa 2016; Diez and Patricio 2016). Although several investigators consider that FP remains a threat to sea turtle conservation worldwide (Jacobson et al. 1991; Aguirre and Lutz 2004; Hamann et al. 2010); others consider that the disease is not a threat to sea turtle population recovery (Chaloupka et al. 2009) or somatic growth rates (Patricio et al. 2015).

Direct shedding and horizontal transmission of the virus through bodily fluids have not been demonstrated (Alfaro-Nunez et al. 2014); however, ChHV5 DNA has been detected in blood, urine and cloacal swabs in green turtles at rehabilitation facilities in southeastern USA (Page-Karjian et al. 2015). In addition, the virus has been identified in saliva and ocular secretions of green turtles with FP in Brazil (Monezi et al. 2016).

The presence of FP in Costa Rica was first suspected in olive ridley turtles (Lepidochelys olivacea) in Ostional $\mathrm{Na}$ tional Wildlife Refuge (NWR) in 1982 (Cornelius and Robinson 1983) and 1987 (Orrego and Morales 2002). Aguirre et al. (1999) confirmed FP histopathologically, and ChHV5 was determined using PCR (Brenes et al. 2013). FP lesions were reported in green turtles on the Nicaraguan Atlantic coast (Herbst 1994; Lagueux et al. 1998).

The objectives of this study were to determine and compare presence of ChHV5 DNA in apparently normal skin and tumor samples with ocular, nasal and cloacal swabs. Samples were collected from two species of free-ranging sea turtles with and without FP in the Pacific coasts of Costa Rica and Nicaragua. In addition, we aimed to evaluate the potential use of swabs as a noninvasive technique for the identification of ChHV5 in apparently healthy turtles.

\section{Methods}

\section{Capture, Clinical Examination and Sampling}

Olive ridley turtles were sampled at nesting sites during arribadas at Ostional NWR $\left(9^{\circ} 57^{\prime} 3^{\prime \prime}, 85^{\circ} 42^{\prime} 3^{\prime \prime}\right)$ in Costa Rica, and La Flor NWR $\left(11^{\circ} 07^{\prime} 0^{\prime \prime}, 85^{\circ} 48^{\prime} 0^{\prime \prime}\right)$ and Chacocente NWR $\left(11^{\circ} 30^{\prime} 3^{\prime \prime}, 86^{\circ} 08^{\prime} 3.7^{\prime \prime}\right)$ in Nicaragua between 2010 and 2013. Green turtles were sampled in Costa Rica at a foraging site located in the Golfo Dulce $\left(83^{\circ} 35^{\prime} 0^{\prime \prime}\right.$, $\left.83^{\circ} 16^{\prime} 0^{\prime \prime}\right)$ and in two nesting sites, Playa Naranjo and Playa Nancite $\left(10^{\circ} 52^{\prime} 9.31^{\prime \prime}, 85^{\circ} 35^{\prime} .27^{\prime \prime}\right)$, both in Santa Rosa National Park (NP) (Figure 1).

Olive ridley turtles were sampled during the "trance stage" at oviposition. Given that FP had been reported in Ostional NWR, olive ridley turtles were randomly sampled without prior determination of FP lesions. Conversely, only olive ridley turtles with FP were sampled in Nicaragua, as there were no prior records of the disease. At the foraging site, green turtles were captured using a $100 \times 3 \mathrm{~m}$ modified fishing net which allowed turtles to surface from the water and breathe, thus preventing animal trauma. The net was thrown into the sea and regularly monitored (every $15 \mathrm{~min}$ ) for $7 \mathrm{~h} /$ day and then removed at the end of the day. Green turtles were captured at nesting sites after laying eggs using a net to immobilize the animal, and the head was wrapped in a towel to minimize stress.

For turtles caught at the foraging site, the curved carapace length was measured to determine size, which was then used for classifying juveniles or adults. According to Seminoff et al. (2007), green turtles with a carapace length of $<75.5 \mathrm{~cm}$ are juveniles and $\geq 75.5 \mathrm{~cm}$ are considered adults. An external general physical exam was performed in situ. During this examination, apparent injuries, trauma, ulcers or tumors were recorded. Three $5 \mathrm{~mm}$ skin biopsies were then collected from the front flippers, in the dorsal 


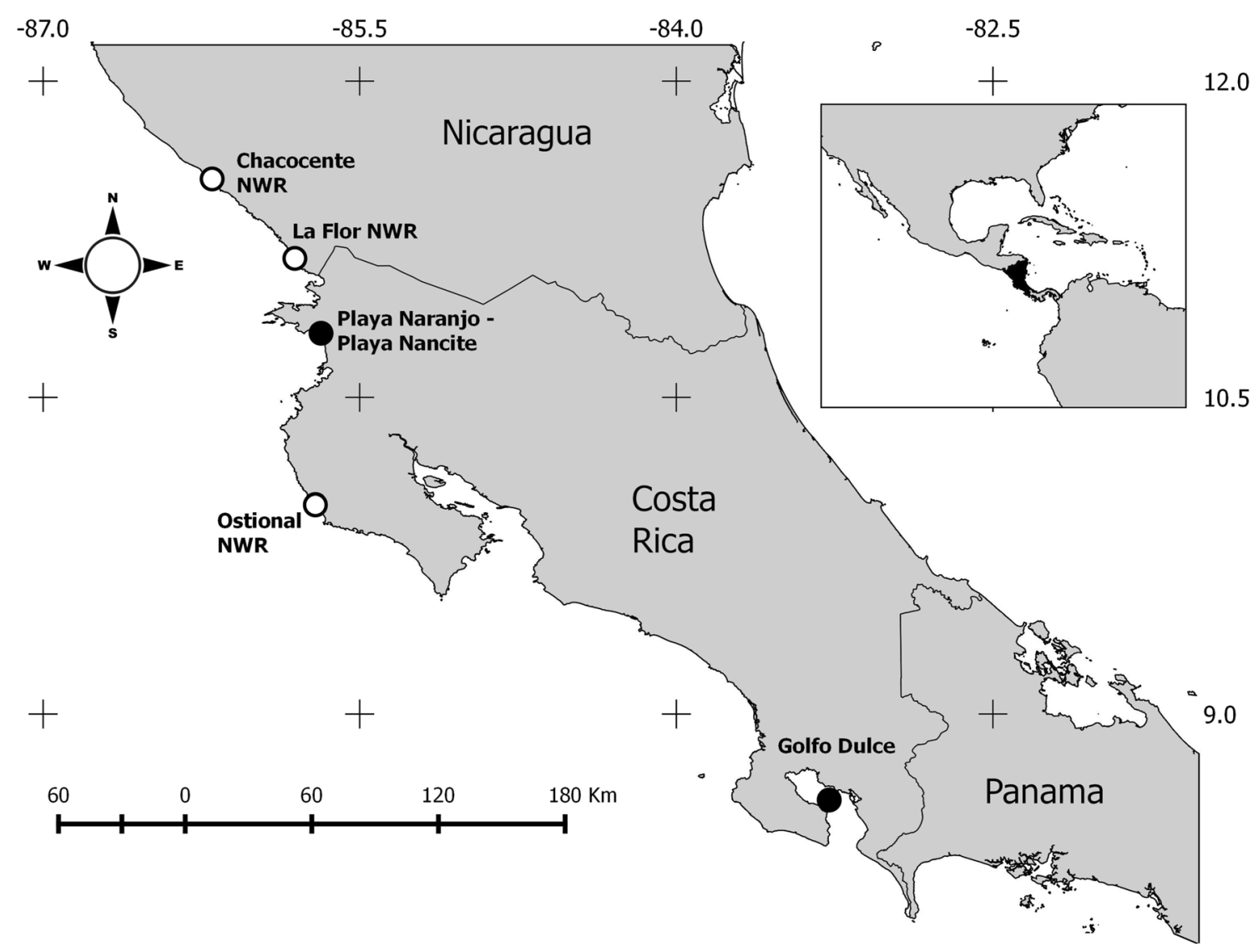

Figure 1. Location of field sites from north to south: Chacocente National Wildlife Refuge (NWR) (arribada) and La Flor NWR (arribada), Nicaragua, Playa Nancite (nesting), Playa Nancite (nesting) in Santa Rosa National Park, Ostional NWR (arribada) and Golfo Dulce, Puerto Jiménez (foraging), Costa Rica. White circles indicate where olive ridley turtles were sampled. Black circles indicate where Pacific green turtles were sampled.

region close to the neck, using a dermal sterile punch (Kruuse, Langeskov, Denmark). This body area was selected for tissue sampling, as the cranial region is primarily associated with the presence of FP-infected tissue (Work et al. 2004). If the turtle was found to have tumors, three additional tumor biopsies were collected. Also ocular, nasal and cloacal swabs were collected with sterile swabs and stored dry in sterile cryovials, one per tube. All samples were frozen in liquid nitrogen and transferred to a $-20^{\circ} \mathrm{C}$ freezer on arrival to the laboratory, where they were stored until analysis, for a maximum of 22 days.

\section{Detection of ChHV5 DNA}

Total genomic DNA was extracted from skin, tumors and swabs, using the DNeasy Blood and Tissue Kit ${ }^{\circledR}$ (Qiagen, Hilden, Germany) according to manufacturer's instructions. The purified DNA samples were used for ChHV5 detection with nested PCR, using the method described by Lu et al.
(2000) to detect all possible UL30 sequences as a ChHV5 consensus PCR, in the Environmental Health Laboratory of the University of Hawaii at Manoa (CITES: Nicaragua08984, Costa Rica-2014-CR81/SJ, USA-12US75218A/9). As a negative control, nuclease-free water was used, and as a positive control a ChHV5 DNA sample was amplified and sequenced from a green turtle with FP confirmed by histopathology. All positives were reamplified, and only the positive reamplified samples were taken as true positives. Afterward, we performed another PCR on positive samples that amplified the $483 \mathrm{bp}$ portion (GTHV2 and GTHV3 primers) of the DNA polymerase. This protocol amplifies a larger sequence length and has been more widely used (Quackenbush et al. 2001). PCR products were visualized on a 2\% agarose gel. Amplicons of the desired size were then purified and sequenced in a commercial laboratory, using a ABI3730XL (Macrogen Inc., Seoul, Korea). The obtained sequences were subjected to BLAST to identify homologous sequences in GenBank and eliminate false positives. 
The sensitivity of the ChHV5-specific PCR assay was tested on a serial tenfold dilutions of DNA positives in AE buffer of the DNA extraction kit to evaluate the detection capacity in oral, nasal and cloacal swab samples. The proportion of viral detection was compared between all the samples positive to ChHV5 DNA (apparently normal skin, tumors and swabs). The ChHV5 DNA-positive control with a known DNA total concentration was used.

The ChHV5 DNA-positive samples from apparently normal skin, tumors and swabs were statistically analyzed using Pearson's Chi-squared test and Fisher's exact test by separating the specimens with and without external FP tumors obtained from different sampling areas. The association between age (juvenile or adult) and presence of ChHV5 DNA was also evaluated for each of the foraging sample sites. These statistical analyses were conducted in R (R-Development Core Team 2012), with a 95\% confidence level. Finally, the level of assay agreement (i.e., any correlation between the detection results from a particular sample type to the other types) using individual samples from the turtles, with and without FP, was evaluated with the tetrachoric correlation coefficient. For this analysis, individual detection results were assigned to each of the sample types (apparently normal skin, the three swab types and tumors) whether they were positive or negative and treated as binary data (presence/absence) in the program TetMat (Uebersax 2006).

\section{Phylogenetic Analysis}

Sequences indentified herein were aligned with ChHV5 DNA polymerase sequences obtained from GenBank using Muscle in MEGA 6.0 (Tamura et al. 2013). Dataset sequences were chosen based on genomic region, geographic location and turtle species (Table S1). Evolutionary history was inferred using the maximum likelihood method based on the Tamura-3 model with discrete Gamma distribution and rate differences among sites (five categories) with invariable sites. The phylogenetic tree was calculated using 1000 replicates. All positions containing gaps and missing data were eliminated. There were a total of 434 positions in the final dataset. Evolutionary analyses were conducted in MEGA 6.0 (Tamura et al. 2013).

\section{Results}

A total of 900 DNA extracts from 215 sea turtles (114 olive ridley and 101 green turtles) were screened for ChHV5 using PCR. Apparently normal skin samples and ocular, nasal and cloacal swabs were examined from 74 olive ridley and 101 green turtles without FP from Costa Rica. In addition, apparently normal skin, tumor samples and ocular, nasal and cloacal swabs from a total 40 olive ridley turtles with FP tumors from Nicaragua were also analyzed. From all these samples, 102/215 (47.4\%) tested positive for ChHV5 DNA, with 41/215 (19.1\%) positive in apparently normal skin, $31 / 40(77.5 \%)$ in tumors, $15 / 215(7 \%)$ in ocular swabs, $11 / 215(5.1 \%)$ in nasal swabs and $4 / 215$ (1.9\%) in cloacal swabs (Table 1).

Samples from positive swabs were diluted starting with $100 \mathrm{ng}$ of DNA total and then compared with apparently normal skin and tumors, using a previous diagnostic protocol (Lu et al. 2000) with a quantitative limit of detection of $0.1 \rho \mathrm{g}$ for all apparently normal skin and tumor samples, and $90 \%$ (27/30) for swab samples. For 10\% (3/30) of swab samples (one nasal and two cloacal swabs), the detection limit was $1 \rho \mathrm{g}$. The reported sensitivity was similar for the three types of DNA samples extracted from swabs (ocular, nasal and cloacal). However, the detection sensitivity for ChHV5 DNA varied considerably when comparing different types of samples in PCR assays analyzed in both turtles with and without FP tumors. The ChHV5 detection was higher $(77.5 \%)$ in individuals with FP as expected. In addition, the proportion of positives was similar upon using apparently normal skin and ocular swabs (13\%). For nasal and cloacal samples, the number of positives was higher in nasal $(17.5 \%)$ than in cloacal swabs $(5 \%)$ for the samples analyzed. The proportion of viral detection in apparently normal skin (16\%) was greater for turtles without FP. These were followed by nasal swabs $(2.29 \%)$ and an equal proportion of viral detection for ocular and cloacal swabs (1.14\%). The overall proportion of viral detection was greater in turtles with FP (Table 2).

The virus was detected in 10/74 (13.5\%) skin samples and $2 / 74(2.7 \%)$ nasal swabs of olive ridley turtles without FP from Ostional NWR. A total of 31/40 (77.5\%) olive ridley turtles with FP from Nicaragua were positive for ChHV5 DNA (Table 1). The morphology and anatomical location of tumors sampled coincide with the data documented in prior investigations, both for olive ridley and green turtles (Brenes et al. 2013). In addition, the severity of the lesions varied from single to multiple tumors of varying sizes. Multiple samples from four turtles were positive, including three with positive FP tumor, ocular and nasal swabs, and one with positive FP tumor, nasal and cloacal swabs (Table 3). 
Table 1. Olive Ridley (Lepidochelys olivacea) and Pacific Green (Chelonia mydas) Turtle Specimens and Samples Positive for Chelonid Alphaherpesvirus 5, Determined Using PCR from Samples Collected: Fibropapilloma (FP), Apparently Normal Skin (NS), Ocular Swab (OS), Nasal Swab (NaS) and Cloacal Swab (CS) in Costa Rica and Nicaragua Between August 2010 and July 2012.

\begin{tabular}{|c|c|c|c|c|c|c|c|c|}
\hline Location & $\begin{array}{l}\text { Sample } \\
\text { site }\end{array}$ & Specie & $\begin{array}{l}\text { Sample } \\
\text { number }^{\mathrm{a}}\end{array}$ & $\begin{array}{l}\text { Sample } \\
\text { type }\end{array}$ & $\begin{array}{c}\text { ChHV5 } \\
\text { positive } \\
\text { samples } \\
(n) \\
\end{array}$ & $\begin{array}{c}\text { Prevalence } \\
(\%)\end{array}$ & $\begin{array}{l}\text { Positive } \\
\text { individuals } \\
\quad(n)\end{array}$ & $\begin{array}{c}\text { Prevalence } \\
(\%)\end{array}$ \\
\hline \multirow{5}{*}{$\begin{array}{c}\text { Golfo } \\
\text { Dulce } \\
\text { Costa Rica }\end{array}$} & \multirow{5}{*}{ Foranging } & \multirow{5}{*}{$\begin{array}{l}\text { Pacific } \\
\text { green } \\
\text { turtle }\end{array}$} & \multirow{5}{*}{77} & NS & 16 & 21 & \multirow{14}{*}{22} & \multirow{14}{*}{22} \\
\hline & & & & OS & 2 & 3 & & \\
\hline & & & & $\mathrm{NaS}$ & 2 & 3 & & \\
\hline & & & & $\mathrm{CS}$ & 2 & 3 & & \\
\hline & & & & Total & 20 & 26 & & \\
\hline \multirow{5}{*}{$\begin{array}{c}\text { Naranjo } \\
\text { beach } \\
\text { Costa Rica }\end{array}$} & \multirow{5}{*}{ Nesting } & \multirow{5}{*}{$\begin{array}{l}\text { Pacific } \\
\text { green } \\
\text { turtle }\end{array}$} & \multirow{5}{*}{16} & NS & 2 & 13 & & \\
\hline & & & & OS & 0 & 0 & & \\
\hline & & & & $\mathrm{NaS}$ & 0 & 0 & & \\
\hline & & & & $\mathrm{CS}$ & 0 & 0 & & \\
\hline & & & & Total & 2 & 13 & & \\
\hline \multirow{4}{*}{$\begin{array}{c}\text { Nancite } \\
\text { beach } \\
\text { Costa Rica }\end{array}$} & \multirow{4}{*}{ Nesting } & \multirow{4}{*}{$\begin{array}{l}\text { Pacific } \\
\text { green } \\
\text { turtle }\end{array}$} & \multirow{4}{*}{8} & NS & 0 & 0 & & \\
\hline & & & & OS & 0 & 0 & & \\
\hline & & & & $\mathrm{NaS}$ & 0 & 0 & & \\
\hline & & & & $\mathrm{CS}$ & 0 & 0 & & \\
\hline \multirow{5}{*}{$\begin{array}{l}\text { Ostional } \\
\text { National } \\
\text { Wildlife } \\
\text { Refuge } \\
\text { Costa Rica }\end{array}$} & \multirow{5}{*}{ Arribada } & \multirow{5}{*}{$\begin{array}{l}\text { Olive } \\
\text { ridley } \\
\text { turtle }\end{array}$} & \multirow{5}{*}{74} & NS & 10 & 14 & \multirow{5}{*}{10} & \multirow{5}{*}{14} \\
\hline & & & & OS & 0 & 0 & & \\
\hline & & & & $\mathrm{NaS}$ & 2 & 3 & & \\
\hline & & & & $\mathrm{CS}$ & 0 & 0 & & \\
\hline & & & & Total & 10 & 14 & & \\
\hline \multirow{6}{*}{$\begin{array}{l}\text { La Flor } \\
\text { National } \\
\text { Wildlife } \\
\text { Refuge } \\
\text { Nicaragua }\end{array}$} & \multirow{6}{*}{ Arribada } & \multirow{6}{*}{$\begin{array}{l}\text { Olive } \\
\text { ridley } \\
\text { turtle }\end{array}$} & \multirow{6}{*}{33} & NS & 12 & 36 & \multirow{12}{*}{31} & \multirow{12}{*}{78} \\
\hline & & & & FP & 25 & 76 & & \\
\hline & & & & OS & 9 & 27 & & \\
\hline & & & & $\mathrm{NaS}$ & 5 & 15 & & \\
\hline & & & & $\mathrm{CS}$ & 2 & 6 & & \\
\hline & & & & Total & 25 & 76 & & \\
\hline \multirow{7}{*}{$\begin{array}{c}\text { Chacocente } \\
\text { National } \\
\text { Wildlife } \\
\text { Refuge } \\
\text { Nicaragua }\end{array}$} & \multirow{6}{*}{ Arribada } & & & NS & 1 & 15 & & \\
\hline & & & & FP & 6 & 86 & & \\
\hline & & $\begin{array}{l}\text { Olive } \\
\text { ridley }\end{array}$ & 7 & OS & 4 & 57 & & \\
\hline & & turtle & & $\mathrm{NaS}$ & 2 & 29 & & \\
\hline & & & & $\mathrm{CS}$ & 0 & 0 & & \\
\hline & & & & Total & 6 & 86 & & \\
\hline & & & 215 & Total & 165 & 77 & 63 & 29 \\
\hline
\end{tabular}

${ }^{a}$ Number of turtles sampled for FP (in observed cases), skin specimens and ocular, nasal and cloacal swabs. 

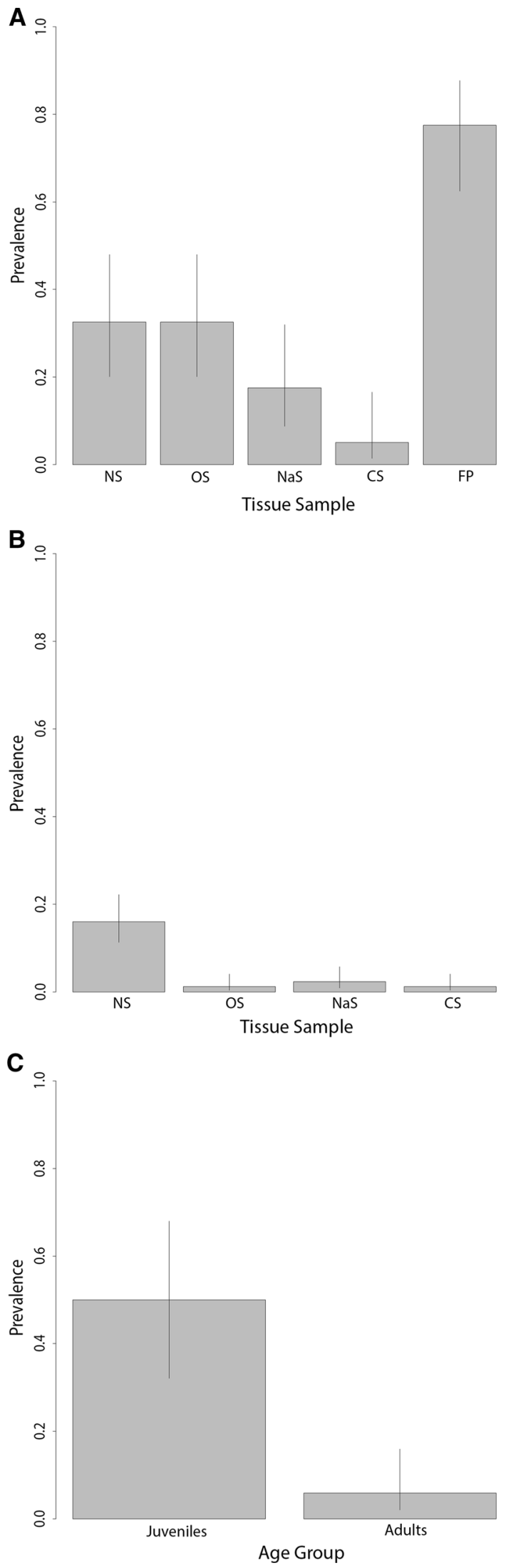

4Figure 2. Prevalence of Chelonid Alphaherpesvirus 5 in olive ridley (Lepidochelys olivacea) and Pacific green (Chelonia mydas) turtles from Costa Rica and Nicaragua between 2010 and 2013. a Prevalence in different sample types of arribada olive ridley turtles, $\mathbf{b}$ prevalence in different sample types of nesting and foraging Pacific green turtles and c prevalence in different age groups of foraging Pacific green turtles. NS apparently normal skin, OS ocular swabs, NaS nasal swabs, CS cloacal swabs, FP fibropapillomas.

A total of 22/101 (22\%) specimens from green turtles without FP from Costa Rica were positive in at least one sample, with apparently normal skin $(18 / 101,17.8 \%)$ being the most common sample found containing the virus (Table 1). Multiple samples from two turtles were found to be positive, and ChHV5 was detected only in swabs for four individuals (two oral, one nasal and one cloacal swab) (Tables 1, 2). From the 77 Pacific green turtles sampled at the foraging site (Golfo Dulce), 51 (66\%) were adults and 26 (34\%) were juveniles. Of the 20 positive individuals, 15/ $26(57.7 \%)$ were juveniles, and 5/51 (9.8\%) were adults.

ChHV5 DNA detection was significantly higher in tumors compared to apparently normal skin samples or swabs $\left(\chi^{2}=24.71, d f=4, p \leq 0.01\right.$; Figure 2). However, the confidence intervals (CI) demonstrated that the ocular swabs and apparently normal skin had the same probability for ChHV5 detection. In addition, ChHV5 DNA was more commonly detected in skin biopsies than in swabs from turtles without FP $\left(\chi^{2}=56.69, d f=3, p \leq 0.01\right.$; Figure 1). Furthermore, juvenile Pacific green turtles had a higher number of positive samples compared to adults $(p \leq 0.01$, odds ratio $=15.27,95 \%$ CI 3.51-96.05; Figure 2).

The level of agreement between individual samples analyzed in turtles with FP showed that the absence of ChHV5 DNA in FP samples is correlated with the absence of ChHV5 DNA in any other sample analyzed. Among the positives of the FP samples, there was a variation in agreement with the other sample types. The highest correlation coefficient value was found between tumor and apparently normal skin, and between tumor and ocular swab ( $r=0.64$, phi $=0.37, p=0.026)$. In general, no correlation was found for the other samples, except between ocular and nasal samples $(r=0.63$, phi $=0.38$, $p=0.038)$. Cloacal samples had a low viral detection. In the case of turtles without FP, the absence of evident tumors agrees with the absence of positive swabs. In addition, a marginal probability between apparently normal skin and nasal swabs was evidenced $(r=0.65$, phi $=0.25, p=0.04$ ). 


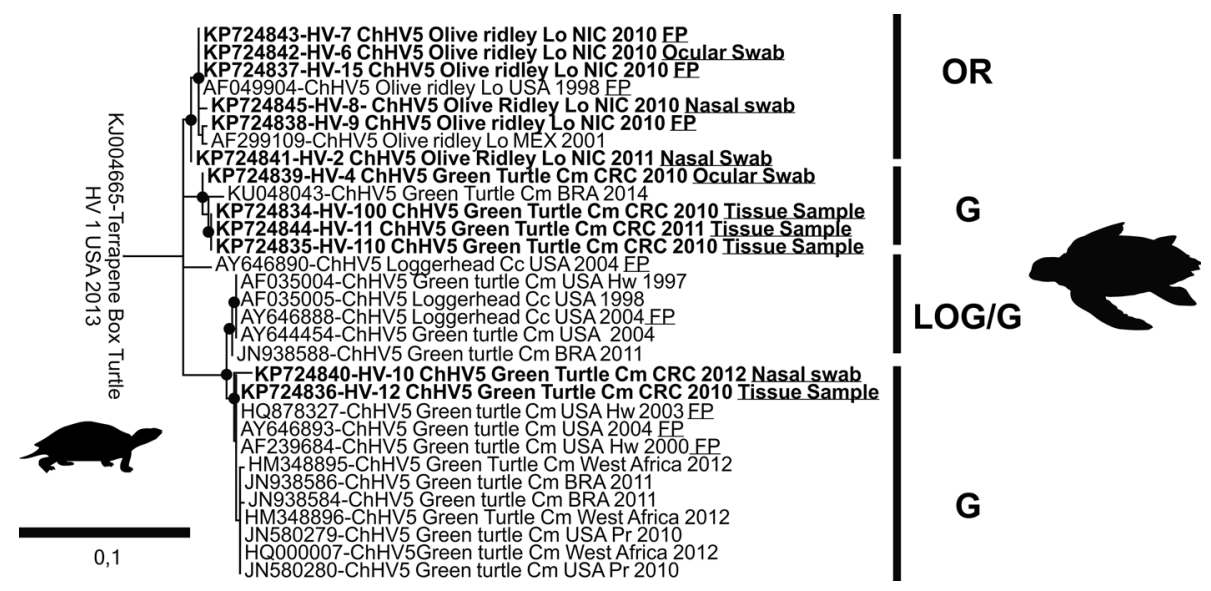

Figure 3. Phylogenetic analysis of Chelonid Alphaherpesvirus 5 based on the 434 bp sequences of UL30. Maximum likelihood method based on the Tamura-3 model with discrete Gamma distribution and rate differences among sites ( 5 categories) with invariable sites. Phylogenetic tree was calculated using 1000 replicates. Circles denote bootstrap values higher than 75\%. Branch lengths show the number of substitutions per site. The analysis involved 31 nucleotide sequences. All positions containing gaps and missing data were eliminated. There were a total of 434 positions in the final dataset. Evolutionary analyses were conducted in MEGA6 (Aguirre et al. 1994). Abbreviations used include olive ridley turtle (OR), green turtle (G), loggerhead turtle and green turtle (LOG/G), Brazil (BRA), Costa Rica (CRC), Mexico (MEX), Nicaragua (NIC), United States of America (USA).

A high homology was observed within the $434 \mathrm{bp}$ sequences of the UL30 polymerase gene (0-5 nucleotide changes) upon performing a genetic analysis (Greenblatt et al. 2005). Two sequences, originating from green turtles in Costa Rica, demonstrated 100\% homology with ChHV5 extracted from a Hawaiian green turtle (GenBank accession number HQ878327) (Ackermann et al. 2012) (Figure 3).

Phylogenetic analyses of the polymerase gene (UL30) demonstrated that the herpesvirus clusters of olive ridley turtles were in a different subgroup of turtle herpesvirus, despite the geographic separation of sequences from Nicaragua, Mexico and USA. The green turtle ChHV5 sequences produced by our study cluster with other herpesviral sequences isolated from green turtles from around world. However, two sequences appeared to be more divergent, clustering in a different subgroup within the ChHV5 with a $94 \%$ bootstrap value. There were no overall genetic differences in this part of the polymerase gene (UL30) detected in apparently normal skin, tumor or swab samples. All sequences obtained were submitted to GenBank (accession numbers KP724834 through KP724845) (Figure 3).

\section{Discussion}

Although the etiology of FP remains speculative, ChHV5 is the leading candidate. This study evaluated the potential for using different biological samples for the detection of
ChHV5 DNA. We compared the use of swabs with invasive tissue sampling for the detection of ChHV5 DNA in turtles with and without FP tumors. The evaluation of a correct amplification of the target sequence was confirmed by sequencing of all positive samples and subsequent comparison with previously reported sequences.

Having confirmed the sensitivity and validity of the technique when using swabs, the differences in the proportion of viral detection, among the different sample types, may be due to the presence of negative samples. Perhaps, samples free of or with very low ChHV5 DNA concentrations might be undetectable by the diagnostic technique employed. The detection accuracy is correlated with the initial concentration of viral DNA samples analyzed and the sensitivity of the technique (Alfaro-Nunez and Gilbert 2014).

Approximately $18 \%$ of swabs were found positive compared to $32 \%$ of apparently normal skin and $77 \%$ of tumors in all turtles sampled. Page-Karjian et al. (2015) analyzed the presence of ChHV5 for urine, feces, cloacal and oral swabs of three groups of turtles in rehabilitation. The presence of ChHV5 in urine $(67,60,11 \%)$ and cloacal swabs $(38,23,13 \%)$ was determined, in addition to those with FP, normal skin and blood samples. Even though in our case, the detection of ChHV5 DNA in cloacal swabs was lower (5\% with FP tumors, 1.14\% without FP tumors), this was probably due to the use of a less sensitive technique compared to Page-Karjian et al. (2015) that used real-time 


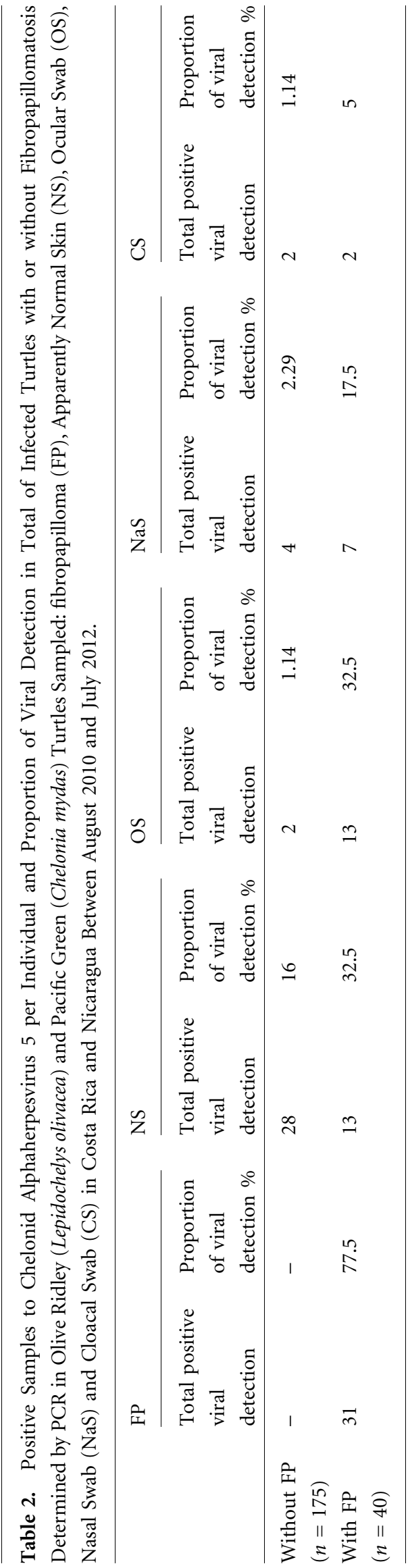

PCR. This is in accordance with a greater detection of ChHV5 DNA in cloacal swabs of turtles with FP tumors.

Monezi et al. (2016) in Brazil detected the presence of ChHV5 in $44 \%$ of ocular swabs and in $21 \%$ of saliva samples, in addition to ocular and skin tumors. In both studies, the percentage of positives was greater in FP tumors and/or normal skin samples. As determined in this study, ocular swabs provided better detection rates (11\%) than other swab samples in turtles with FP, despite only three $(7.5 \%)$ of sample turtles presenting with ocular FP tumors. This suggests a possible affinity of the virus to be excreted in ocular fluid, presuming that it is transmitted during the primary infection, or the activation of a latent infection, promoting the dissemination of the virus through body fluids, which is common in herpesvirus (Davison 2002).

Our results demonstrate a potential virus transmission pathway other than direct contact, as previously suggested (Herbst and Klein 1995; Herbst et al. 1996; Work et al. 2004; Page-Karjian et al. 2015; Monezi et al. 2016). This is in addition to the ChHV5 detection agreement between ocular and nasal swabs, which may be explained biologically by the proximity between these two anatomical zones (Wyneken 2001).

These results demonstrate that swabs are not an ideal diagnostic method when compared to tissue specimens in turtles without FP tumors. For example, some turtles without FP tumors were positive for ChHV5 DNA only on swab samples; on the other hand, some turtles with FP tumors had both, positive tumors and swabs, but not apparently normal skin. A combination of swab collection in addition to normal skin and/or tumor biopsies is recommended in studies related to possible routes of viral transmission. Recent studies recommend other PCR protocols which may be more sensitive and should be taken into consideration in future studies (Alfaro-Nunez and Gilbert 2014; Page-Karjian et al. 2015).

The identification of ChHV5 DNA in tumor samples (86\% in Chacocente, $76 \%$ in La Flor) is consistent with the potential role of ChHV5 in the etiology of FP (Quackenbush et al. 1998; Lu et al. 2000). It should be considered that due to potentially lower sensitivity of the technique used compared to recent studies (Alfaro-Nunez and Gilbert 2014), 100\% positives were not obtained. These authors upon combining the detection results of three individual primer sets, with different targeted gene (UL18 + UL22 + UL27), achieved a 100\% detection in ChHV5 DNA samples, thus increasing the sensitivity obtained. 
Table 3. Comparison of Samples taken from the Same Olive Ridley (Lepidochelys olivacea) or Pacific Green (Chelonia mydas) Turtles Positives to Chelonid Alphaherpesvirus 5 DNA, Determined by PCR on Samples Collected: Fibropapilloma (FP), Apparently Normal Skin (NS), Ocular Swab (OS), Nasal Swab $(\mathrm{NaS})$ and Cloacal Swab (CS) in Costa Rica and Nicaragua Between August 2010 and July 2012.

\begin{tabular}{|c|c|c|c|c|c|c|c|}
\hline \multirow{2}{*}{$\begin{array}{c}\text { Site of } \\
\text { Specimen } \\
\text { collection }\end{array}$} & \multirow{2}{*}{ Location } & \multirow{2}{*}{$n$} & \multicolumn{5}{|c|}{ Specimen type } \\
\hline & & & FP & NS & OS & $\mathrm{NaS}$ & CS \\
\hline \multirow{12}{*}{ Arribada } & $\begin{array}{l}\text { Ostional NWR } \\
\text { (without FP) }\end{array}$ & 2 & & 8 & & 8 & \\
\hline & \multirow{8}{*}{ La Flor (with FP) } & 1 & 0 & 0 & - & 0 & \\
\hline & & 3 & 0 & 0 & 0 & & \\
\hline & & 1 & 0 & 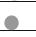 & & 0 & \\
\hline & & 1 & 0 & 0 & & & 웅 \\
\hline & & 6 & 0 & 0 & & & \\
\hline & & 2 & 0 & & 0 & 0 & \\
\hline & & 1 & 0 & & & 0 & - \\
\hline & & 3 & 0 & & O & & \\
\hline & \multirow{3}{*}{$\begin{array}{l}\text { Chacocente NWR } \\
\text { (with FP) }\end{array}$} & 1 & 0 & - & e & e & \\
\hline & & 1 & - & & 0 & 0 & \\
\hline & & 2 & 0 & & 0 & & \\
\hline \multirow[t]{2}{*}{ Foraging } & \multirow{2}{*}{$\begin{array}{l}\text { Golfo Dulce } \\
\text { (without FP) }\end{array}$} & 1 & & 0 & & 0 & \\
\hline & & 1 & & - & & & 0 \\
\hline \multirow[t]{2}{*}{ Nesting } & $\begin{array}{l}\text { Naranjo beach } \\
\text { (without FP) }\end{array}$ & 0 & & & & & \\
\hline & Total & & & & & & \\
\hline
\end{tabular}

The size of the circles is proportional to the number of positive samples for the same type of sample.

Tumors are the best specimen for viral detection (Work et al. 2014). However, recent PCR-based studies have demonstrated that large proportions of asymptomatic marine turtles are also carriers of ChHV5 (Alfaro-Nunez et al. 2016). The presence of ChHV5 DNA in apparently normal skin of turtles without FP tumors may represent an early infection or latent infection, suggesting that these turtles may eventually develop FP or may be asymptomatic reservoirs (Quackenbush et al. 2001; Alfaro-Nunez et al. 2014). Tumor regression has been documented, indicating subclinical infections in which there was no evidence of neoplasia (Machado Guimarães et al. 2013; Page-Karjian et al. 2012, 2014).

Our study confirmed the presence and agreement with detection of ChHV5 DNA in apparently normal skin (32\%) of turtles with FP. Lu et al. (2000) reported a herpesvirus prevalence of $57 \%$ in normal skin specimens from Hawaiian green turtles, while Page-Karjian et al. (2012) reported $48 \%$ of positives in biopsies taken from normal skin samples in animals with FP in Puerto Rico.

Our findings in turtles without FP in Costa Rica are similar to those reported by Quackenbush et al. (2001) who showed a prevalence of $21 \%$ in green and $15 \%$ in logger- head turtles from Australia. Page-Karjian et al. (2012) reported that $32 \%$ of the normal skin samples were found to be positive for ChHV5 DNA. In contrast, all skin samples from stranded green turtles without FP were found to be negative for herpesvirus in Florida (Lackovich et al. 1999). Two studies conducted in normal skin samples from green turtles in Hawaii were found to be negative (Lu et al. 2000; Quackenbush et al. 1998). The differences may be due to the sensitivity of the assay or sample size utilized which reduce the possibility of detecting positive individuals. On the other hand, the observed differences may simply be due to sampling turtles in geographic regions with a very low prevalence.

We did not observe any turtles with FP tumors in Ostional NWR, contrary to previous findings (Cornelius and Robinson 1983; Aguirre et al. 1999; Orrego and Morales 2002; Brenes et al. 2013). According to Aguirre et al. (1999), approximately $6-10 \%$ of nesting females presented observable cutaneous FP, with $1 \%$ being severely affected (an average of 300,000 turtles nest at Ostional each month). It is possible that the lack of evidence for turtles with FP tumors is due to random sampling without specifically searching for individuals with tumors.

Golfo Dulce was the only sea turtle foraging site sampled, in which all turtles without FP were in good body condition. Patricio et al. (2015) demonstrated that there is no relationship between FP and the corporal condition of turtles analyzed. The virus prevalence was significantly higher in juvenile turtles (58\%), consistent with previous reports (George 1997; Murakawa et al. 2000). Van Houtan et al. (2010) found that all models have shown that subadults are the age cohort most affected by ChHV5. This disease appears to be closely linked to unfavorable environmental conditions (Herbst and Klein 1995; Van Houtan et al. 2010), which highlights the importance of protecting the foraging sites, as this is where they reside for long periods of time (Amorocho and Reina 2007; Amorocho et al. 2012).

The partial sequences (UL30) in this study were found to be highly homologous and similar sequences clustered together regardless of location, time of sampling or sampling procedure. There is a clear separation between ChHV5 sequences found in olive ridley and Pacific green/ loggerhead turtles. However for loggerhead and Pacific green turtle ChHV5 sequences, even if a certain clustering is observed in interior nodes, the low bootstrap support of the exterior nodes makes difficult to accurately determine the phylogenetic position. The detection of herpesvirus se- 
quences in different swab samples may represent individuals that currently have an active infection, and these infected turtles may be a source of horizontal infection (PageKarjian et al. 2015; Monezi et al. 2016). It is important to perform quantitative analyses that measure the viral replication in corporal fluids demonstrating an active infection with capacity of transmission. In addition, a more sensitive diagnostic technique is recommended and preferably quantitative (Alfaro-Nunez and Gilbert 2014; Page-Karjian et al. 2015).

Two of the Pacific green turtles sequences found in this study (KP724836-KP724840) grouped with others found in the USA, Brazil and Africa. Golfo Dulce is a foraging site that is widely visited by turtles from different geographic regions, which may favor the transmission of the pathogen and could explain this phylogenetic arrangement described herein. Similar distribution has been observed in ChHV5 positive green turtles which acquired the infection during their juvenile stage in neritic habitats (Aguirre et al. 1994; Ene et al. 2005). More complex phylogenetic inferences were beyond the scope of the analysis performed in this study.

\section{CONCLUSION}

This is the first report of detection of ChHV5 DNA in Pacific green turtles from Costa Rica and olive ridley turtles from Nicaragua. The monitoring of FP in sea turtles is an indicator of the health of marine ecosystems (Aguirre and Lutz 2004; Flint et al. 2010) and contributes in the rapid recognition of disease manifestation by conservation managers, who can then initiate prevention and control measures, focused on the protection of natural areas for the prevention and control of accumulated anthropogenic change (coastal pollution, agrochemicals, intensive fisheries, urbanization, among others). For this reason, the use of sensitive molecular techniques is indispensable that allow for the detection of ChHV5 DNA in different biological tissues that favor the detection of early infections. Further research into the etiology, host species transmission, disease ecology and long-term global impacts of FP are required.

\section{ACKNOWLEDGEMENTS}

We are grateful to all contributors who selflessly assisted with various sampling endeavors, especially Ricardo
Jiménez, Karen Vega and Martha Sarmento in the Golfo Dulce; Laura Badilla and Wilbert Villachica in Santa Rosa NP; Laura Brenes and Carolina Salas in Ostional NWR, Costa Rica; Carlos Mario Orrego, Adriana Espinosa and Oscar Sánchez in La Flor NWR and Chacocente NWR, Nicaragua. This work was supported by the Fondo de Educación Superior Estatal del Consejo Nacional de Rectores de Costa Rica (CONARE), the Ministry of Science and Technology of Costa Rica and the Fishing Law of Costa Rica. The diagnostic tests were supported by the Environmental Health Laboratory at the University of Hawaii at Manoa. We would also like to thank the National System of Conservation Areas (SINAC), the Ministry of Environment and Energy (MINAE) of Costa Rica and the Ministry of Environment and Natural Resources (MARENA) of Nicaragua. Collect permit numbers: MARENA-Nicaragua: MARENA-DM-JAS0523.04.2009; MINAET-SINAC-Costa Rica: SINAC-SE-GASP-PI-202 Cites Permit numbers: USA, 12US75218A/9, Costa Rica, 2014-CR81/SJ.

\section{REFERENCES}

Ackermann M, Koriabine M, Hartmann-Fritsch F, de Jong PJ, Lewis TD, Schetle N, Work TM, Dagenais J, Balazs GH, Leong JAC (2012) The genome of chelonid herpesvirus 5 harbors atypical genes. PLoS One 7:e46623

Aguirre AA, Balazs GH, Zimmerman B, Spraker TR (1994) Evaluation of Hawaiian green turtles (Chelonia mydas) for potential pathogens associated with fibropapillomas. J Wildl Dis 30:8-15

Aguirre AA, Spraker TR, Chaves A, Du Toit L, Eure W, Balazs GH (1999) Pathology of fibropapillomatosis in olive ridley turtles Lepidochelys Olivacea nesting in Costa Rica. Journal of Aquatic Animal Health 11:283-289

Aguirre AA, Lutz PL (2004) Marine turtles as sentinels of ecosystem health: is fibropapillomatosis an indicator? EcoHealth 1:275-283

Alfaro-Nunez A, Gilbert M (2014) Validation of a sensitive PCR assay for the detection for fibropapilloma-associated herpesvirus Chelonid in latent infections turtle. Journal of Virological Methods 206:38-41

Alfaro-Nunez A, Frost Bertelsen M, Bojesen A, Rasmussen I, Zepeda-Mendoza L, Tange Olsen M, Gilbert M (2014) Global distribution of chelonid fibropapilloma-associated herpesvirus among clinically healthy sea turtles. BMC Evolutionary Biology $14: 206$

Alfaro-Nunez A, Bojesen AM, Bertelsen MF, Wales N, Balazs GH, Gilbert MTP (2016) Further evidence of Chelonid herpesvirus 5 (ChHV5) latency: high levels of ChHV5 DNA detected in clinically healthy marine turtles. PeerJ 4:e2274

Amorocho D, Reina R (2007) Feeding ecology of the East Pacific green sea turtle Chelonia mydas at Gorgona National Park, Colombia. Endangered Species Research 3:43-51 
Amorocho D, Abreu-Grobois A, Dutton P, Reina R (2012) Multiple distant origins for green sea turtles aggregating off Gorgona Island in the Colombian Eastern Pacific. PLoS One $7: 1-12$

Baptistotte C (2016) Fibropapillomatosis in sea turtles from South America-Brazil, Uruguay and Argentina. In: Proceedings of the 2015 International Summit on Fibropapillomatosis: Global Status, Trends, and Population Impacts. NOAA TM NMFS-PIFSC Hargrove S, Work T, Brunson S, Foley AM, Balazs G (compilers), vol 54, pp 22-25

Brenes L, Berrocal A, Meneses AI, Jiménez C, Orrego C (2013) Study on the etiology of fibropapillomatosis of olive ridley sea turtles (Lepidochelys olivacea) nesting in the National Wildlife Refuge at Ostional, Guanacaste, Costa Rica. Revista Ciencias Marinas y Costeras 15:119-134

Chaloupka M, Balazs GH, Work TM (2009) Rise and fall over 26 years of a marine epizootic in Hawaiian green sea turtles. Journal of Wildlife Diseases 45:1138-1142

Coberley SS, Herbst LH, Brown DR, Ehrhart LM, Bagley DA, Hirama S, Jacobson ER, Klein PA (2001) Detection of antibodies to a disease-associated herpesvirus of the green turtle, Chelonia mydas. Journal of Clinical Microbiology 39:3572-3577

Coberley SS, Herbst LH, Ehrhary LM, Bagley DA, Hirama S, Jacobson ER, Klein PA (2001b) Survey of Florida green turtles for exposure to a disease-associated herpesvirus. Diseases of Aquatic Organisms 47:159-167

Cornelius SE, Robinson DC (1983) Abundance, distribution, and movements of olive ridley sea turtles in Costa Rica, III. U.S. Fish and Wildlife Service Endangered Species Report 13, Albuquerque, New Mexico

Davison AJ (2002) Evolution of the herpesviruses. Veterinary Microbiology 86:69-88

Diez CE, Patricio R (2016) Fibropapillomatosis in marine turtles of the Caribbean Region: the case study of Puerto Rico. In: Proceedings of the 2015 International Summit on Fibropapillomatosis: Global Status, Trends, and Population Impacts. NOAA TM NMFS-PIFSC Hargrove S, Work T, Brunson S, Foley AM, Balazs G (compilers), vol 54, pp 8-11

Ehrhart L, Redfoot W, Mansfield K, Gorham J, Weege S, Provancha J (2016) In: Proceedings of the 2015 International Summit on Fibropapillomatosis: Global Status, Trends, and Population Impacts. NOAA TM NMFS-PIFSC Hargrove S, Work T, Brunson S, Foley AM, Balazs G (compilers), vol 54, pp 15-21

Ene A, Su M, Lemaire S, Rose C, Schaff S, Moretti R, Lenz J, Herbst LH (2005) Distribution of chelonid fibropapillomatosisassociated herpesvirus variants in Florida: molecular genetic evidence for infection of turtles following recruitment to neritic developmental habitats. Journal of Wildlife Diseases 41(3):489497

Flint M, Patterson-Kane JC, Limpus CJ, Mills PC (2010) Health surveillance in stranded green sea turtles in southern Queensland, Australia (2006-2009): an epidemiological analysis of the causes of disease and mortality in marine turtles. EcoHealth $7: 135-145$

George RH (1997) Health problems and diseases of sea turtles. In: The Biology of Sea Turtles, Lutz PL, Musick JA (editors), Boca Raton, Florida: CRC Press, pp 363-385

Greenblatt RJ, Quackenbush SL, Casey RN, Rovnak J, Balazs GH, Work TM, Casey JW, Sutton CA (2005) Genomic variation of the fibropapilloma-associated marine turtle herpesvirus across seven geographic areas and three host species. Journal of Virology 79:1125-1132
Hamann M, Godfrey MH, Seminof JA, Arthur K, Barata PCR, Bjorndal KA, Bolten AB, Broderick AC, Campbell LM, Carreras C, et al. (2010) Global research priorities for sea turtles: informing management and conservation in the $21^{\text {st }}$ century. Endangered Species Research 11:245-269

Harshbarger JC (1991) Sea turtle fibropapilloma cases in the registry of tumors in lower animals. In Balazs GH, Pooley SG (compilers). Research plan for marine turtle fibropapilloma. NOAA TM NMFS-SWFSC 156:63-70

Herbst LH (1994) Fibropapillomatosis of marine turtles. Annual Review of Fish Diseases 4:389-425

Herbst LH, Klein PA (1995) Green turtle fibropapillomatosis: challenges to assessing the role of environmental cofactors. Environmental Health Perspectives 103:27-30

Herbst LH, Moretti R, Brown T, Klein PA (1996) Sensitivity of the transmissible green turtle fibropapillomatosis agent to chloroform and ultracentrifugation conditions. Diseases of Aquatic Organisms 25:225-228

Herbst LH, Jacobson ER, Klein PA, Balazs GH, Moretti R, Brown T, Sundberg JP (1999) Comparative pathology and pathogenesis of spontaneous and experimentally induced fibropapillomas of green turtles (Chelonia mydas). Vet Pathol 36:551-564

Herbst LH, Lemaire S, Ene AR, Heslin DJ, Ehrhart LM, Bagley DA, Klein PA, Lenz J (2008) Use of baculovirus-expressed glycoprotein $\mathrm{H}$ in an enzyme-linked immunosorbent assay developed to assess exposure to chelonid fibropapillomatosisassociated herpesvirus and its relationship to the prevalence of fibropapillomatosis in sea turtles. Clin Vaccine Immunol 15:843851

Jacobson ER, Buergelt C, Williams B, Harrls RK (1991) Herpesvirus in cutaneous fibropapillomas of the green turtle Chelonla mydas. Diseases of Aquatic Organisms 12:1-6

Lagueux CJ, Campbell CL, Herbst LH (1998) Characterization of fibropapilloma occurrence in a Nicaraguan green turtle fishery. In: Proceedings of the 16th Annual Symposium on Sea Turtle Biology and Conservation, Hilton Head, South Carolina, 28 February-1 March. NOAA TM NMFS-SEFSC Byles R, Fernandez Y (compilers), vol 412, p 90

Lackovich JK, Brown DR, Homer BL, Garber RL, Mader DR, Moretti RH, Patterson AD, Herbst LH, Oros J, et al. (1999) Association of herpesvirus with fibropapillomatosis of the green turtle Chelonia mydas and the loggerhead turtle Caretta caretta in Florida. Diseases of Aquatic Organisms 37:89-97

Limpus CJ, Jones K, Chaloupka M (2016). Fibropapilloma disease in marine turtles in Eastern Indian Ocean-South Western Pacific Ocean. In: Proceedings of the 2015 International Summit on Fibropapillomatosis: Global Status, Trends, and Population Impacts. NOAA TM NMFS-PIFSC, Hargrove S, Work T, Brunson S, Foley AM, Balazs G (compilers), vol 54, pp 36-43

Lu Y, Wang Y, Yu Q, Aguirre AA, Balazs GH, Nerurkar VR (2000) Detection of herpesviral sequences in tissues of green turtles with fibropapilloma by polymerase chain reaction. Archives of Virology 145:1885-1893

Lucke B (1938) Studies on tumors in cold-blooded vertebrates. Annual Report of the Tortugas Laboratory of the Camegie Institute 1937:92-94

Machado Guimarães S, Mas Gitirana H, Vidal Wanderley A, Monteiro-Neto C, Lobo-Hajdu G (2013) Evidence of regression of fibropapillomas in juvenile green turtles Chelonia mydas caught in Niterói, southeast Brazil. Diseases of Aquatic Organisms 102:243-247 
Monezi TA, Mehnert DU, de Moura EMM, Müller NMG, Garrafa P, Matushima ER, Werneck MR, Borella MI (2016) Chelonid herpesvirus 5 in secretions and tumor tissues from green turtles (Chelonia mydas) from Southeastern Brazil: A ten-year study. Veterinary microbiology 186:150-156

Murakawa SKK, Balazs GH, Ellis DM, Hau S, Eames SM (2000) Trends in fibropapillomatosis among green turtles stranded in the Hawaiian Islands, 1982-98. In: Proceedings of the 19th Annual Symposium on Sea Turtle Conservation and Biology. NOAA TM NMFS- SEFSC, Kalb HI, Wibbels T (compilers), vol 443, pp 239-241

Murakawa SKK (2016) Hawaiian Archipelago Fibropapillomatosis Data. In: Proceedings of the 2015 International Summit on Fibropapillomatosis: Global Status, Trends, and Population Impacts. NOAA TM NMFS-PIFSC, Hargrove S, Work T, Brunson S, Foley AM, Balazs G (compilers), vol 54, pp 44-56

Orrego CM, Morales JA (2002) Discoveries of olive ridley turtles (Lepidochelys olivacea) on the Pacific coast of Costa Rica. In: Proceedings of the 22nd Annual Symposium on Sea Turtle Biology and Conservation. Miami, Florida NOAA Technical Memorandum. NMFS-SEFSC Mosler A, Brost B (compilers), vol 477, pp 276-277

Page-Karjian A, Torres F, Zhang J, Rivera S, Diez C, Moore PA, Moore D, Brown C (2012) Presence of CHFPV in tumored and non-tumored green turtles, as detected by PCR, in endemic and non-endemic aggregations. Puerto Rico. Springerplus 1:35

Page-Karjian A, Norton TM, Krimer P, Groner M, Nelson SE, Gottdenker NL (2014) Factors influencing survivorship of rehabilitating green sea turtles (Chelonia mydas) with fibropapillomatosis. Journal of Zoo and Wildlife Medicine 45:507-519

Page-Karjian A, Norton TM, Ritchie B, Brown CC, Mancia C, Jackwood M, Gottdenker NL (2015) Quantifying chelonid herpesvirus 5 in symptomatic and asymptomatic rehabilitating green sea turtles. Endangered Species Research 28:135-146

Patricio AR, Diez CE, van Dam RP, Godley BJ (2015) Novel insights into the dynamics of green turtle fibropapillomatosis. Marine Ecology Progress Series 547:247-255

Quackenbush SL, Work TM, Balazs GH, Casey RN, Rovnak J, Chaves A, du Toit L, Baines JD, Parrish CR, Bowser PR, Casey
JW (1998) Three closely related herpesviruses are associated with fibropapillomatosis in marine turtles. Virology 246:392-399

Quackenbush SL, Casey RN, Murcek RJ, Paul TA, Work TM, Limpus CJ, Chaves A, du Toit L, Vasconcelos Perez J, Aguirre AA, Spraker TR, Horrocks JA, Vermeer LA, Balazs GH, Casey JW (2001) Quantitative analysis of herpesvirus sequences from normal tissue and fibropapillomas of marine turtles with realtime PCR. Virology 287:105-111

Seminoff JA, Reséndiz-Hidalgo A, de Reséndiz BJ, Nichols WJ, Todd-Jones T (2007) Aspectos bioecológicos: tortugas marinas. In: Bahía de los Angeles: Recursos Naturales y Comunidad. Pronatura Noroeste A.C., Secretaría de Medio Ambiente y Recursos Naturales, Danemann GD, Ezcurra E (compilers), Instituto Nacional de Ecología y Museo de Historia Natural de San Diego, Mexico, pp 454-494

Smith GM, Coates CW (1938) Fibro-epithelial growths of the skin in large marine turtles, Chelonia mydas (Linnaeus). Zoologica New York 23:93-98

Tamura K, Stecher G, Peterson D, Filipski A, Kumar S (2013) MEGA6: Molecular Evolutionary Genetics Analysis version 6.0. Molecular Biology and Evolution 30:2725-2729

Uebersax JS (2006) Computer program documentation. TetMat User Guide 1.0

Van Houtan KS, Hargrove SK, Balazs GH (2010) Land use, macroalgae, and a tumor-forming disease in marine turtles. PLoS One 5:e12900

Wyneken J (2001) The Anatomy of Sea Turtles. U.S. Department of Commerce NOAA Technical Memorandum NMFS-SEFSC470, pp 1-172

Work TM, Balazs GH, Rameyer RA, Morris R (2004) Retrospective pathology survey of green turtles (Chelonia mydas) with fibropapillomatosis from the Hawaiian Islands, 1993-2003. Diseases of Aquatic Organisms 62:163-176

Work TM, Dagenais J, Balazs GH, Schettle N, Ackermann M (2014) Dynamics of virus shedding and in situ confirmation of chelonid herpesvirus 5 in Hawaiian green turtles with fibropapillomatosis. Veterinary Pathology 52:1195-1201 